\title{
Effects of hexazinone and atrazine on the physiology and endocrinology of smolt development in Atlantic salmon
}

\author{
Katherine Nieves-Puigdoller ${ }^{\mathrm{a}, *}$, Björn Thrandur Björnsson ${ }^{\mathrm{b}}$, Stephen D. McCormick ${ }^{\mathrm{a}}$ \\ ${ }^{a}$ Department of Natural Resources Conservation and Organismic and Evolutionary Biology, University of Massachusetts, USGS, \\ Leetown Science Center, Conte Anadromous Fish Research Center, Turners Falls, Amherst, MA 01003, USA \\ ${ }^{\mathrm{b}}$ Fish Endocrinology Laboratory, Department of Zoology/Zoophysiology, Göteborg University, Box 463, S40530 Göteborg, Sweden
}

Received 24 February 2007; received in revised form 17 May 2007; accepted 22 May 2007

\begin{abstract}
Exposure to hexazinone (HEX) and atrazine (ATZ), highly mobile and widely used herbicides along rivers in the United States, is potentially harmful to Atlantic salmon, which have been listed as an endangered species. To determine the effects of these contaminants on smolt development, juvenile Atlantic salmon were exposed under flow-through conditions to $100 \mu \mathrm{g} \mathrm{l}^{-1} \mathrm{HEX}, 10$ and $100 \mu \mathrm{g} \mathrm{l}^{-1} \mathrm{ATZ}$ in fresh water (FW) for 21 days at $10^{\circ} \mathrm{C}$ beginning in mid-April. Twelve fish per treatment were sampled in FW, following a $24 \mathrm{~h}$ seawater (SW) challenge and after growth for 3 months in SW. Exposure to $100 \mu \mathrm{g}^{-1} \mathrm{HEX}$ or $10 \mu \mathrm{g} \mathrm{l}^{-1}$ ATZ caused no mortalities of smolts in FW or after SW challenge, while $9 \%$ of the fish exposed to $100 \mu \mathrm{gl}^{-1}$ ATZ died during exposure. Fish exposed to $100 \mu \mathrm{g} 1^{-1}$ ATZ reduced feeding after 10 days of exposure and had an impaired growth rate in FW and during the first month in SW; compensatory growth occurred in the second and third month in SW. HEX and ATZ at $10 \mu \mathrm{g}^{-1}$ exposure had no effect on plasma levels of cortisol, growth hormone (GH), insulin growth factor I (IGF-I), thyroxine ( $\mathrm{T}_{4}$ ) and plasma 3,5,3'-triiodo-L-thyronine $\left(\mathrm{T}_{3}\right), \mathrm{Cl}^{-}, \mathrm{Mg}^{2+}, \mathrm{Na}^{+}, \mathrm{Ca}^{2+}$ in FW or after SW challenge. FW smolts exposed to $100 \mu \mathrm{g} \mathrm{l}^{-1} \mathrm{ATZ}$ had decreased plasma $\mathrm{Cl}^{-}, \mathrm{Mg}^{2+}, \mathrm{Na}^{+}$and $\mathrm{Ca}^{2+}$ ions and increased cortisol. No effect on plasma levels of GH, IGF-I, $\mathrm{T}_{4}$ or $\mathrm{T}_{3}$ was found in FW smolts exposed to $100 \mu \mathrm{gl}^{-1}$ ATZ. Following SW challenge, fish previously exposed to $100 \mu \mathrm{gl}^{-1}$ ATZ had significant increases in hematocrit, plasma cortisol, $\mathrm{Cl}^{-}, \mathrm{Mg}^{2+}, \mathrm{Na}^{+}, \mathrm{Ca}^{2+}$ and a decrease in $\mathrm{T}_{4}$ and $\mathrm{T}_{3}$. It is concluded that under the conditions imposed in this study, HEX does not affect salinity tolerance of Atlantic salmon smolts, while ATZ causes ionoregulatory, growth and endocrine disturbance.
\end{abstract}

(C) 2007 Elsevier B.V. All rights reserved.

Keywords: Atlantic salmon; Hexazinone; Atrazine; Osmoregulation; Smolt; Hormone

\section{Introduction}

The number of adult salmon returning to rivers in Europe and North America has been declining for more than a century, and river contamination has been implicated as a causative factor for these population declines (Parrish et al., 1998). As part of their anadromous life history, salmon undergo a transformation from stream-dwelling parr to downstream migrating smolts. This transformation includes a number of morphological, behavioral and physiological changes that are adaptive for downstream migration and seawater entry (Hoar, 1988). Prominent among these changes is an increase in salinity tolerance,

\footnotetext{
* Corresponding author at: USGS Conte Anadromous Fish Research Center, Box 796 One Migratory Way, Turners Falls, MA 01376, USA. Tel.: +1 413863 3804; fax: +1 4138639810 .

E-mail address: knievesp@forwild.umass.edu (K. Nieves-Puigdoller).
}

which is the result of a reorganization of the major osmoregulatory organs, the gill, gut and kidney. The development of salinity tolerance is accompanied by an increase in the scope for growth in seawater. Gill $\mathrm{Na}^{+}, \mathrm{K}^{+}$-ATPase activity is a widely used marker for these ion regulatory changes and is strongly correlated with the development of seawater tolerance in smolts (Hoar, 1988).

A number hormones are involved in controlling the parrsmolt transformation. Cortisol, growth hormones $(\mathrm{GH})$ and insulin like growth factor I (IGF-I) are known to be directly involved in the development of seawater tolerance, as well as other aspects of smolt development (McCormick, 2001). Thyroid hormones (thyroxine $\left(\mathrm{T}_{4}\right)$ and 3,5,3'-triiodo-L-thyronine $\left(\mathrm{T}_{3}\right)$ ) have an indirect role in ion regulation, but more directly control morphological and behavioral changes. Recent studies have shown that this endocrine driven process is sensitive to contaminants that act as endocrine disruptors (Madsen et al., 2004; McCormick et al., 2005; Lerner et al., 2007). 
Hexazinone (HEX) and atrazine (ATZ) are non-selective herbicides in the triazine family that are often applied during spring to control undesirable plants. Due to its high application and water solubility, both pesticides can be detected in run-off water at concentrations up to $275 \mu \mathrm{g} \mathrm{l}^{-1}$ (Huber, 1993). In Maine, this is especially problematic because HEX and ATZ are used primarily in areas immediately adjacent to rivers where Atlantic salmon breed and spend their early life history.

No published data are available on the effects of HEX on parrsmolt transformation or SW tolerance. Documented effects of ATZ in fish include a slow down in reflexes, swimming activity and feeding (Hussein et al., 1996). ATZ can also cause damage to gill epithelium and kidneys, increasing the renal excretion of sodium, chloride and proteins in rainbow trout (Oncorhynchus mykiss) (Fisher-Scherl et al., 1991) and carp (Cyprinus carpio L.) (Neskovic et al., 1993). Furthermore, ATZ reduces plasma testosterone and olfactory sensitivity in mature male Atlantic salmon (Moore and Waring, 1998). Waring and Moore (2004) found that atrazine exposure for 7 days reduces salinity tolerance of Atlantic salmon. However, the mechanism by which ATZ impacts salinity tolerance has yet to be established. In particular, the effects of ATZ and HEX on the hormones involved in smolt development have not been examined.

The objective of this study was to determine the effect of environmentally relevant concentrations of HEX and ATZ on, survival, growth and ion regulation in fresh water and seawater, gill $\mathrm{Na}^{+}, \mathrm{K}^{+}$-ATPase activity and the major hormones that promote smolt development (cortisol, GH, IGF-I, $\mathrm{T}_{4}$ and $\mathrm{T}_{3}$ ) in Atlantic salmon. We also examined whether ATZ and HEX were stressors by examining the primary and secondary stress response (plasma cortisol and glucose).

\section{Materials and methods}

\subsection{Fish rearing and treatment}

Atlantic salmon parr were obtained from White River National Fish Hatchery (Bethel, VT) in the fall of 2002 and transported to the Conte Anadromous Fish Research Center (Turners Falls, MA). Parr were raised in 1.6-m diameter tanks with Connecticut River water at a flow rate of 6-81 $\mathrm{min}^{-1}$ under natural photoperiod and supplemental aeration. Fish were fed to satiation twice daily with a specific salmon formulated dry feed (Zeigler Bros., Gardners, PA, USA).

\subsection{Chemical exposure}

Atrazine concentrations were based on field and laboratory levels reported in previous studies (Moore et al., 2003; Spano et al., 2004; Waring and Moore, 2004; Alvarez and Fuiman, 2005). Hexazinone concentrations were based on preliminary studies (Nieves-Puigdoller and McCormick, unpublished data) where no significant effect of HEX was found on survival, ion regulation and plasma hormones of Atlantic salmon smolts exposed to environmentally relevant concentrations of 2, 20 and $200 \mu \mathrm{g}^{-1}$ HEX. Fish were exposed to chemicals for 21 days, a time period that has been widely used as a proxy for long-term exposure
(Davies et al., 1994; Baatrup and Junge, 2001; Spano et al., 2004; Lerner et al., 2007). Exposure began approximately 1month prior to the beginning of normal downstream migration and the peak of smolt development based on previous lab studies (McCormick et al., 1995).

On April 24, 2003, 1-year-old Atlantic salmon parr large enough to become smolt ( $>25 \mathrm{~g}$ ) were exposed for 21 days at $10{ }^{\circ} \mathrm{C}$ to $0,10,100 \mu \mathrm{g} \mathrm{ATZ} 1^{-1}$ (purity 98\%, Chemservice) and $100 \mu \mathrm{g} \mathrm{HEX}^{-1}$ (generic name for Velpar, 75\% HEX and 25\% inert ingredients, Dupont Company) in 3001 tanks (2 tanks per treatment, 18 fish per tank, 144 fish total). All the tanks had supplemental, constant aeration and oxygen measured twice per week were always greater than $90 \%$ saturation. Both compounds were prepared daily by dissolving them in water. A peristaltic pump (Cole-Palmer Instrument Co., Vernon Hills, IL, USA) was used to add the stock solutions of ATZ and HEX to a head tank. ATZ and HEX were mixed by a water pump with dechlorinated tap water and delivered to the fish tanks at a rate of $11 \mathrm{~min}^{-1}$. Water samples were taken and stored at $-80{ }^{\circ} \mathrm{C}$ before analysis of HEX or ATZ concentrations. Fish were sampled immediately following exposure as describe below.

\subsection{Fish sampling}

After 21 days of exposured, 12 fish per treatment (6 per tank) were sampled in FW, another 12 smolt per treatment were exposed to a $24 \mathrm{~h} \mathrm{SW}$ challenge (30 ppt), and another 12 smolt per treatment (9 for $100 \mu \mathrm{g}^{-1}$ ATZ) were reared in SW (30 ppt) tank at $10 \pm 1{ }^{\circ} \mathrm{C}$ for 3 months. For the salmon reared in SW for 3 months, 10 fish per treatment were individually marked with intraperitoneal passive integrated transponder (PIT) tags and then transferred to a 1.6-m diameter SW tank. The SW tank contained $25 \mathrm{ppt} \mathrm{SW}$ for the first week and then the salinity was increased to $30 \mathrm{ppt}$. Fish were fed to satiation daily. Every 4 weeks, all the fish were dip-netted, anesthetized, blot-dried, and fork length and weight were measured.

Specific growth rate (SGR) for weight and length were calculated each month using the following formula (Brett and Groves, 1979):

$\mathrm{SGR}=\left[\left(\log _{\mathrm{e}} W_{t}-\log _{\mathrm{e}} W_{0}\right) \times t^{-1}\right] \times 100$

where $W_{\mathrm{t}}$ is the final weight or length, $W_{0}$ the initial weight or length and $t$ is the time in days.

At the time of sampling, fish were anesthetized in $100 \mathrm{mg}^{-1}$ tricaine methanesulfonate (MS-222, pH 7.0) and weight and fork length measured to the nearest $0.1 \mathrm{~g}$ and $\mathrm{mm}$. Fish were bled from the caudal blood vessels into heparized syringes within 6 min of the first tank disturbance. Hematocrit was measured using microhematocrit capillary tubes. The remaining blood was centrifuged at $3000 \times g$ for $5 \mathrm{~min}$, and the plasma was aliquoted and stored at $-80^{\circ} \mathrm{C}$ until analysis. Brains were removed, weighed and frozen at $-80^{\circ} \mathrm{C}$ for measurement of cholinesterase activity. Gill biopsies of five or six filaments were placed in $100 \mu$ l of ice-cold SEI ( $250 \mathrm{mM}$ sucrose, $10 \mathrm{mM}$ $\mathrm{Na}_{2}$ EDTA and $50 \mathrm{mM}$ imidazole, $\mathrm{pH} 7.3$ ) buffer and stored at $-80{ }^{\circ} \mathrm{C}$ for measurements of gill $\mathrm{Na}^{+}, \mathrm{K}^{+}$-ATPase activity. As 
an index of possible impacts on the reproductive axis, liver and gonads were weighed and expressed relative to body weight (gonadosomatic index, GSI, and hepatosomatic index, HSI).

Estimates of food consumption were made on days 10 and 15 by weighing out $3.0 \mathrm{~g}$ of feed (estimated maximum daily ration) for each tank. Small increments of this were fed to each tank until fish were sated. The observer could see both the movement of fish toward feed and any accumulation of food on the bottom of the tank. Once feeding behavior stopped and more than one or two pellets were observed on the bottom of the tank, fish were deemed to be sated. The amount of food eaten was expressed as grams food per kilogram fish.

\subsection{Analytical methods}

Plasma sodium, calcium and magnesium ions were measured in duplicate with a flame atomic absorption spectrophotometer (AAnalyst 100, Perkin-Elmer, Norwalk, CT, USA). Plasma chloride was measured using a digital Buchler-Cotlove Chloridometer (Model 442-5000, Labconco). Plasma glucose was measured by enzymatic coupling with hexokinase and glucose6-phosphate dehydrogenase (Stein, 1963). Plasma protein was determined with a bicinchoninic acid (BCA) protein assay (Pierce, Rockford, IL, USA).

Plasma cortisol was determined with a enzyme immunoassay as outlined in by Carey and McCormick (1998). Plasma thyroxine $\left(\mathrm{T}_{4}\right)$ and plasma 3,5,3'-triiodo-L-thyronine $\left(\mathrm{T}_{3}\right)$ were measured by radioimmunoassay (Dickhoff et al., 1978) as modified by McCormick et al. (1995). Plasma growth hormone was determined with a specific double-antibody salmon growth hormone radioimmunoassay (Bolton et al., 1986) as modified and validated for Atlantic salmon by Björnsson et al. (1994). Plasma IGF-I was measured by radioimmunoassay validated for salmonids (Moriyama et al., 1994).

Gill $\mathrm{Na}^{+}, \mathrm{K}^{+}$-ATPase activity was determined using a microassay method as outlined in McCormick (1993). Gill tissue was homogenized in $125 \mu \mathrm{l}$ of SEI buffer with a Kontes pellet pestle motor for $10-15 \mathrm{~s}$, then centrifuged at $5000 \times g$ for $0.5 \mathrm{~min}$. Ten microliters of homogenate in quadruplicate were pipetted into a 96-well plate. Each sample had two wells containing an assay mixture with ouabain $(0.5 \mathrm{mM})$ and two wells containing an assay mixture without ouabain. The kinetic assay was read at a wavelength of $340 \mathrm{~nm}$ at $25^{\circ} \mathrm{C}$ for $10 \mathrm{~min}$. Ouabain-sensitive ATPase activity was detected by the enzymatic coupling of ATP dephophorylation to NADH oxidation. The gill homogenate protein concentration was determined using the BCA protein assay using bovine serum albumin as standard. $\mathrm{Na}^{+}, \mathrm{K}^{+}$-ATPase activity was expressed as micromoles ADP per milligram protein per hour.

Brain cholinesterase activity was measured in order to determine whether the observed lethargy at high doses of ATZ was due to changes in this enzyme. Brain cholinesterase activity was determined by a colorimetric method of Ellman et al. (1961) as modified by Ceron et al. (1996). Whole brains were homogenized in a dilution of 1:50 with $0.1 \mathrm{M}$ phosphate buffer, $\mathrm{pH}$ 8 using a manual Potter-Elvehjem homogenizer. Five microliters of homogenate in quadruplicate were pipetted into a 96-well plate. Each sample had two wells containing $200 \mu \mathrm{l}$ assay mixture of acetylthiocholine iodide $(1 \mathrm{mM})$ and $5,5^{\prime}$ dithio-bis(2-nitrobenzoic acid) (DTNB) $(80 \mathrm{nM})$ and two wells containing $200 \mu \mathrm{l}$ DTNB. The kinetic assay used was read at a wavelength of $405 \mathrm{~nm}$ at $25^{\circ} \mathrm{C}$ for $7 \mathrm{~min}$. Cholinesterase activity was expressed as micromoles acetylthiocholine hydrolyzed per milligram protein per hour. The brain homogenate protein concentration was determined using the BCA protein.

\subsection{Water analysis}

Water levels of ATZ and HEX were analyzed using solid phase extraction $\mathrm{C} 18$ cartridge followed by gas chromatography-mass spectrophotometer (GC-MS) determination (Lyytikäinen et al., 2003; Palma et al., 2004). ATZ and HEX were not detected in the control tanks. Water was analyzed in duplicates and data represent mean values \pm S.E.

\subsection{Statistics}

All data are expressed as mean \pm standard error. No tank effects were found for any parameter $(P>0.05$, one-way ANOVA). Therefore, data for replicate tanks were pooled for further analyses. Analyses were run on ranked data because data for some parameters failed to meet the assumptions of parametric statistics. The treatment effect in FW or SW was analyzed by a one-way analysis of variance (ANOVA). Two-way ANOVA was used to examine the effect of treatment and sex on HSI and GSI. No significant sex differences were found for other parameters (two-way ANOVA). Significant ANOVA effects were followed by a Dunnett's test. Statistical significance was taken at a level of $P<0.05$.

\section{Results}

Water levels of ATZ at the end of the treatment period were $8.5 \pm 1.1$ and $84.3 \pm 1.3 \mu \mathrm{g} 1^{-1}$, compared with nominal concentrations of 10 and $100 \mu \mathrm{gl}^{-1}$, respectively. The mean value of HEX was $79.8 \pm 2.1 \mu \mathrm{gl}^{-1}$ for nominal concentration of $100 \mu \mathrm{g} 1^{-1}$.

Exposure to ATZ $\left(100 \mu \mathrm{g}^{-1}\right)$ caused a $9 \%$ mortality of the fish in FW over the 21 days of treatment. There were no other mortalities in FW or SW in smolt treated with HEX or $10 \mu \mathrm{g} 1^{-1}$ ATZ. In control tanks, fish would move rapidly around tank in response to daily observations for mortality. In contrast, 2 weeks of exposure to ATZ $100 \mu \mathrm{g} 1^{-1}$ resulted in decreased responsiveness to this external disturbance. Fish exposed to $100 \mu \mathrm{g} 1^{-1}$ ATZ had reduced food consumption after 10 and 15 days of exposure (Table 1). There was no significant difference in weight or length in FW or after SW challenge in smolt exposed to $100 \mu \mathrm{g} \mathrm{l}^{-1} \mathrm{HEX}, 10 \mu \mathrm{g} 1^{-1}$ ATZ or $100 \mu \mathrm{g}{ }^{-1}$ ATZ (Table 2). An increase in hematocrit was observed for smolts exposed to 10 and $100 \mu \mathrm{gl}^{-1} \mathrm{ATZ}$ after the SW challenge. No significant difference in hematocrit was observed for HEX-treated fish (Table 2). Exposure to ATZ and HEX did not affect plasma levels of GH or IGF-I in FW or after $24 \mathrm{~h} \mathrm{SW}$ challenge (Table 2). 
Table 1

Estimated feed intake at days 10 and 15 of exposure to $100 \mu \mathrm{g} 1^{-1} \mathrm{HEX}, 10$ and $100 \mu \mathrm{g} 1^{-1}$ ATZ in fresh water

\begin{tabular}{lll}
\hline Treatment & $\begin{array}{l}\text { Day 10 } \\
\text { Feed intake }(\mathrm{g}) / \mathrm{fish} \\
(\mathrm{kg}) \text { Tank 1/Tank 2 }\end{array}$ & $\begin{array}{l}\text { Day 15 } \\
\text { Feed intake }(\mathrm{g}) / \mathrm{fish} \\
(\mathrm{kg}) \text { Tank 1/Tank 2 }\end{array}$ \\
\hline Control & $81 / 93$ & $81 / 93$ \\
$100 \mu \mathrm{g} \mathrm{I}^{-1} \mathrm{HEX}$ & $93 / 81$ & $93 / 81$ \\
$10 \mu \mathrm{g} \mathrm{l}^{-1} \mathrm{ATZ}$ & $79 / 78$ & $79 / 78$ \\
$100 \mu \mathrm{gl}^{-1} \mathrm{ATZ}$ & $26 / 11^{*}$ & $0 / 0^{*}$ \\
\hline
\end{tabular}

Values are expressed per kg of fish (18 fish/tank) measured at the end of exposure period. Asterisks (*) indicate a significant difference from control $(P<0.05$, one-way ANOVA, Dunnett's test).

Exposure to HEX or ATZ did not affect the levels of brain cholinesterase (Table 2). A significant increase of HSI was found in females exposed to $100 \mu \mathrm{gl}^{-1}$ ATZ (Table 3). No significant difference in HSI was observed in the other treatments. Male GSI decreased significantly in smolt exposed to $100 \mu \mathrm{g} \mathrm{l^{-1 }}$ ATZ (Table 3). No significant changes in GSI were found in the other treatments.

Plasma $\mathrm{Na}^{+}$increased significantly in $\mathrm{FW}$ smolts treated with $10 \mu \mathrm{g}{ }^{-1}$ ATZ, but decreased in fish exposed to $100 \mu \mathrm{g} 1^{-1}$ ATZ (Fig. 1). Plasma $\mathrm{Na}^{+}, \mathrm{Cl}^{-}, \mathrm{Ca}^{2+}$ and $\mathrm{Mg}^{2+}$ decreased in fish exposed to $100 \mu \mathrm{gl}^{-1} \mathrm{ATZ}$ in FW and increased significantly in SW challenged smolts (Fig. 1). HEX exposure had no effect on plasma levels of $\mathrm{Cl}^{-}, \mathrm{Mg}^{2+}, \mathrm{Na}^{+}$or $\mathrm{Ca}^{2+}$ in $\mathrm{FW}$ or after $24 \mathrm{~h} \mathrm{SW}$ challenge. Gill $\mathrm{Na}^{+}, \mathrm{K}^{+}$-ATPase activity decreased significantly in FW smolts treated with $100 \mu \mathrm{g} \mathrm{l}^{-1} \mathrm{HEX}$ in FW and $100 \mu \mathrm{g} \mathrm{l}^{-1}$ ATZ after $24 \mathrm{~h} \mathrm{SW}$ challenge (Fig. 1).

Plasma glucose and cortisol were significantly elevated in smolts treated with $100 \mu \mathrm{gl}^{-1}$ ATZ in FW and after SW challenge (Table 2). No significant changes in levels of cortisol were found in other treatments (Fig. 2). Plasma $\mathrm{T}_{4}$ was reduced in smolt exposed to $10 \mu \mathrm{gl}^{-1}$ ATZ in FW (Fig. 2). Smolts treated with $100 \mu \mathrm{g} \mathrm{l}^{-1}$ ATZ had reduced plasma $\mathrm{T}_{4}$ and $\mathrm{T}_{3}$ levels after $24 \mathrm{~h} \mathrm{SW}$ exposure (Fig. 2). Plasma protein levels were significantly higher in fish exposed to $100 \mu \mathrm{g} 1^{-1}$ ATZ in FW and after the SW challenge (Table 2).

Significant reduction in weight and length were found in smolt exposed to $100 \mu \mathrm{g} 1^{-1}$ ATZ on May 15 and June 4 in SW (Fig. 3). No significant differences from control were found in smolt treated with $100 \mu \mathrm{g}{ }^{-1}$ HEX and $10 \mu g l^{-1}$ ATZ. Specific growth rate for weight were lower in fish exposed to $100 \mu \mathrm{gl}^{-1}$ ATZ, during the first month in SW (Table 4). A significant increase in weight and length SGR was observed in smolts treated with $100 \mu \mathrm{g} \mathrm{l}^{-1}$ ATZ during the second and third month (Table 4). The growth rate of control, as well as fish exposed to $100 \mu \mathrm{g} 1^{-1}$ HEX and $10 \mu \mathrm{g}^{-1}$ ATZ did not differ form controls after transfer to SW.

\section{Discussion}

The present study demonstrates that exposure to $100 \mu \mathrm{g} 1^{-1}$ ATZ (actual $84 \mu \mathrm{g}^{-1}$ ) can cause osmoregulatory disturbance, physiological stress and reduction in food intake and growth

Table 2

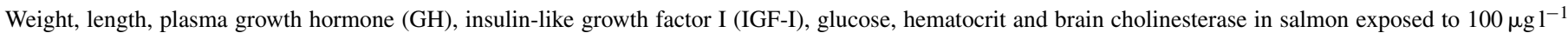
HEX, 10 and $100 \mu \mathrm{g}^{-1}$ ATZ for 21 days in fresh water and after $24 \mathrm{~h}$ seawater challenge

\begin{tabular}{|c|c|c|c|c|c|c|c|}
\hline Treatments & Weight (g) & Length $(\mathrm{cm})$ & $\mathrm{GH}\left(\mathrm{ng} \mathrm{ml}^{-1}\right)$ & IGF-I $\left(\mathrm{ng} \mathrm{ml}^{-1}\right)$ & $\begin{array}{l}\text { Plasma glucose } \\
(\mathrm{mM})\end{array}$ & Hematocrit (\%) & $\begin{array}{l}\text { Brain cholinesterase } \\
(\mu \mathrm{mol} / \mathrm{mg} \text { protein } / \mathrm{h})\end{array}$ \\
\hline \multicolumn{8}{|l|}{ Fresh water } \\
\hline Control & $37.0 \pm 1.4$ & $16.0 \pm 0.2$ & $14.0 \pm 2.5$ & $54.0 \pm 4.2$ & $5.3 \pm 1.1$ & ND & $39.7 \pm 2.2$ \\
\hline $100 \mu g 1^{-1} \mathrm{HEX}$ & $37.6 \pm 1.4$ & $16.1 \pm 0.2$ & $8.2 \pm 2.5$ & $58.9 \pm 4.5$ & $6.3 \pm 1.0$ & ND & $46.3 \pm 2.2$ \\
\hline $10 \mu \mathrm{g}{ }^{-1}$ ATZ & $40.1 \pm 1.4$ & $16.4 \pm 0.2$ & $14.6 \pm 4.1$ & $61.8 \pm 4.5$ & $5.4 \pm 1.6$ & ND & $46.6 \pm 2.2$ \\
\hline $100 \mu \mathrm{g} \mathrm{l}^{-1} \mathrm{ATZ}$ & $35.8 \pm 1.5$ & $15.8 \pm 0.2$ & $21.6 \pm 5.0$ & $44.3 \pm 3.6$ & $20.4 \pm 1.5^{*}$ & ND & $49.9 \pm 2.2$ \\
\hline \multicolumn{8}{|l|}{ Seawater } \\
\hline Control & $35.4 \pm 2.1$ & $15.8 \pm 0.3$ & $21.8 \pm 2.6$ & $39.6 \pm 2.5$ & $3.6 \pm 0.5$ & $33.5 \pm 1.5$ & ND \\
\hline $100 \mu g 1^{-1}$ HEX & $40.2 \pm 2.1$ & $16.4 \pm 0.3$ & $18.4 \pm 2.8$ & $47.9 \pm 4.1$ & $4.2 \pm 0.2$ & $37.5 \pm 1.4$ & ND \\
\hline $10 \mu \mathrm{gl}^{-1} \mathrm{ATZ}$ & $38.7 \pm 2.1$ & $16.5 \pm 0.3$ & $10.1 \pm 2.7$ & $46.6 \pm 2.9$ & $3.9 \pm 0.5$ & $50.1 \pm 1.8^{*}$ & ND \\
\hline $100 \mu \mathrm{g}^{-1} \mathrm{ATZ}$ & $32.0 \pm 2.1$ & $15.4 \pm 0.3$ & $17.9 \pm 3.1$ & $42.3 \pm 2.1$ & $6.3 \pm 0.5^{*}$ & $44.7 \pm 2.0^{*}$ & ND \\
\hline
\end{tabular}

Data represent mean values \pm S.E. of $n=12$ fish per treatment. ND, No determined data. Significant difference from controls is indicated by an asterisk $(P<0.05$, one-way ANOVA, Dunnett's test).

Table 3

Hepatosomatic and gonadosomatic index in salmon exposed to $100 \mu \mathrm{g} 1^{-1} \mathrm{HEX}, 10$ and $100 \mu \mathrm{g} 1^{-1}$ ATZ for 21 days in fresh water

\begin{tabular}{|c|c|c|c|c|}
\hline \multirow{2}{*}{$\begin{array}{l}\text { Treatments } \\
\text { Fresh water }\end{array}$} & \multicolumn{2}{|l|}{ HIS (\%) } & \multicolumn{2}{|l|}{ GSI (\%) } \\
\hline & Male & Female & Male & Female \\
\hline Control & $0.56 \pm 0.03$ & $0.57 \pm 0.08$ & $0.031 \pm 0.004$ & $0.221 \pm 0.019$ \\
\hline $100 \mu \mathrm{g} 1^{-1} \mathrm{HEX}$ & $0.66 \pm 0.01$ & $0.71 \pm 0.02$ & $0.029 \pm 0.001$ & $0.206 \pm 0.030$ \\
\hline $10 \mu \mathrm{gl}^{-1}$ ATZ & $0.72 \pm 0.03$ & $0.65 \pm 0.05$ & $0.030 \pm 0.004$ & $0.235 \pm 0.028$ \\
\hline $100 \mu \mathrm{g} 1^{-1}$ ATZ & $0.73 \pm 0.04$ & $0.92 \pm 0.12^{*}$ & $0.019 \pm 0.005^{*}$ & $0.169 \pm 0.054$ \\
\hline
\end{tabular}

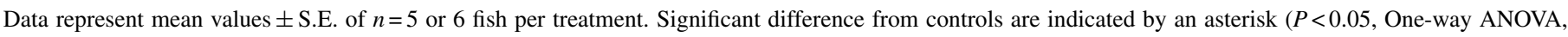
Dunnett's test). 

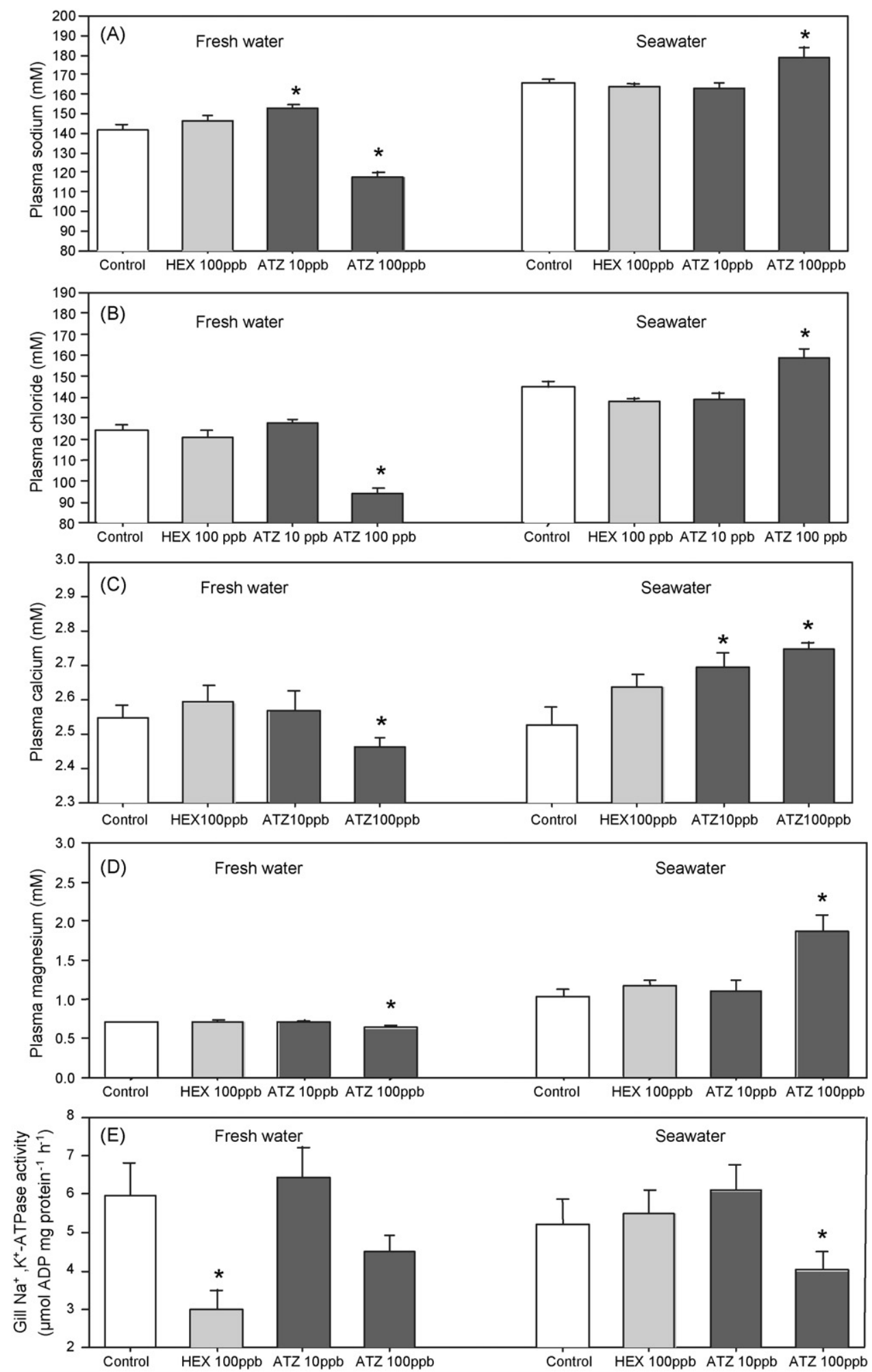

Fig. 1. Plasma sodium (A), plasma chloride (B), plasma calcium (C) and plasma magnesium (D) in smolt exposed to $100 \mu \mathrm{g} 1^{-1}$ hexazinone, 10 and $100 \mu \mathrm{g} 1^{-1}$ atrazine for 21 days in fresh water and after $24 \mathrm{~h}$ seawater challenge. Gill $\mathrm{Na}^{+}, \mathrm{K}^{+}$-ATPase activity (E) in smolt exposed to $100 \mu \mathrm{g}{ }^{-1}$ hexazinone, 10 and $100 \mu \mathrm{g} 1^{-1}$ atrazine for 21 days in fresh water and after $24 \mathrm{~h}$ seawater challenge. Significant differences from controls are indicated by an asterisk $(P<0.05$, Dunnett's test). Values are means \pm S.E., $n=12$ fish per treatment.

of Atlantic salmon smolts. Smolts exposed to $100 \mu \mathrm{g} 1^{-1}$ ATZ for 21 days in FW had lower plasma levels of monovalent and divalent ions. Similar decreases in plasma $\mathrm{Na}^{+}$and $\mathrm{Cl}^{-}$have been observed in Nile tilapia (Oreochromis niloticus) and catfish
(Chrysichthyes auratus) after being exposed to high concentrations of ATZ (3 and $6 \mathrm{mgl}^{-1}$; Hussein et al., 1996). After a 14-days exposure, high concentrations $\left(1.5-6 \mathrm{mg} \mathrm{l}^{-1}\right)$ of ATZ can cause hyperplasia and fusion of the secondary lamellae in 

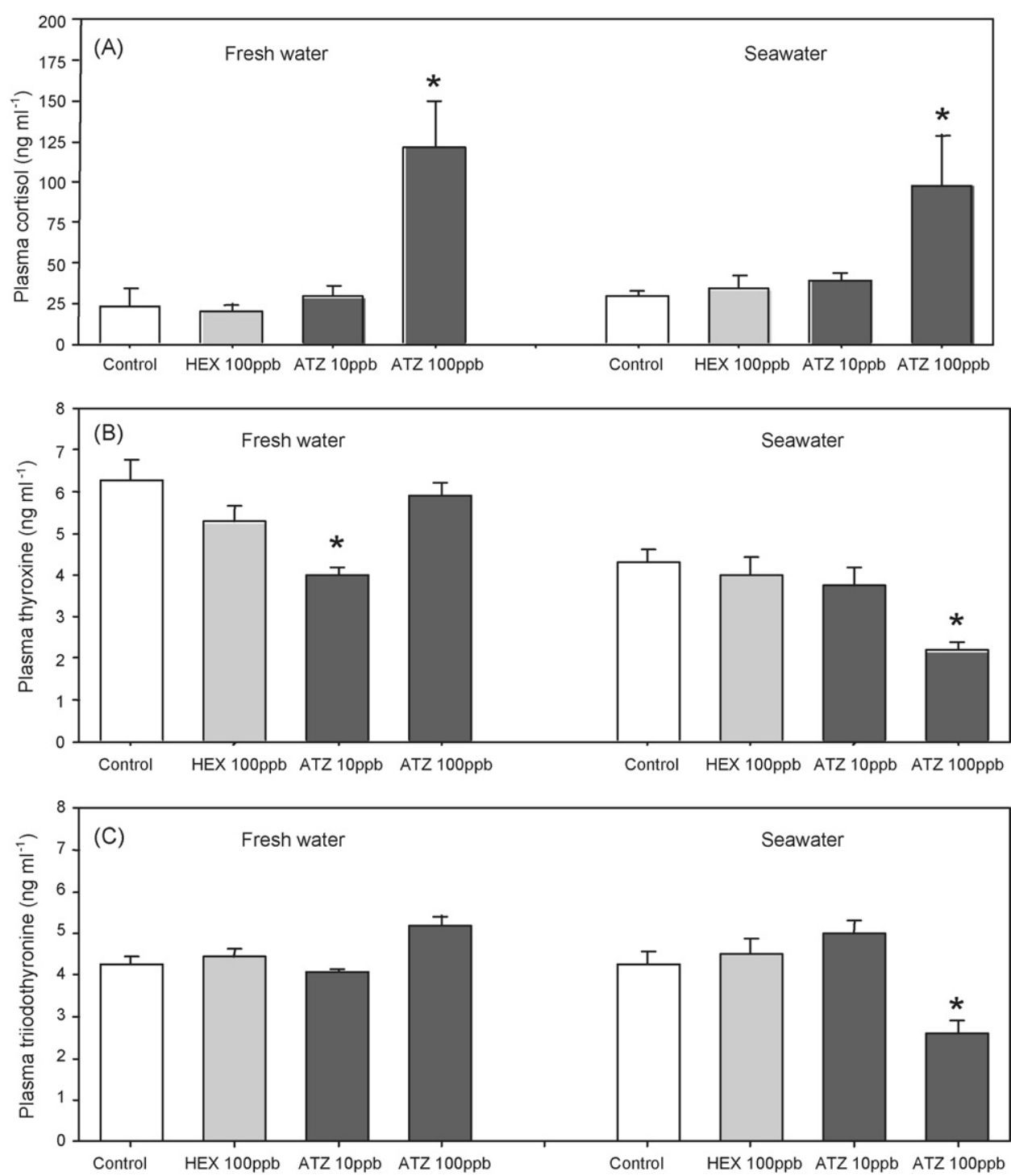

Fig. 2. Plasma cortisol (A), thyroxine (B) and 3,5,3'-triiodo-L-thyronine (C) in smolt exposed to $100 \mu \mathrm{g} 1^{-1}$ hexazinone, 10 and $100 \mu \mathrm{g} 1^{-1}$ atrazine in fresh water and after $24 \mathrm{~h}$ seawater challenge. Significant differences from controls are indicated by an asterisk $(P<0.05$, Dunnett's test). Values are means \pm standard errors, $n=12$ fish per treatment.

the gill epithelium of carp that, in turn, affects osmoregulation (Neskovic et al., 1993). In addition to effects on the gill, impairment of the kidney function may also play a role in the observed loss of plasma ions. Fisher-Scherl et al. (1991) and Oulmi et al. (1995) showed that ATZ concentrations between
10 and $80 \mu \mathrm{g} 1^{-1}$ can cause degeneration in the proximal tubules of the kidneys of rainbow trout, which may increase the renal excretion of ions and proteins.

Elevated plasma $\mathrm{Na}^{+}$and $\mathrm{Cl}^{-}$following SW challenge indicate that exposure to $100 \mu \mathrm{g} \mathrm{l}^{-1}$ ATZ decreases salinity tol-

Table 4

Three months specific growth rate (SGR) in seawater smolts previously treated for 21 days with 10 and $100 \mu \mathrm{g} 1^{-1}$ ATZ, and $100 \mu g 1^{-1} \mathrm{HEX}$

\begin{tabular}{|c|c|c|c|c|c|c|}
\hline \multirow{2}{*}{$\begin{array}{l}\text { Treatments } \\
\text { Fresh water }\end{array}$} & \multicolumn{2}{|l|}{ May 15-June4 } & \multicolumn{2}{|l|}{ June 4-July 1} & \multicolumn{2}{|l|}{ July 1-July31 } \\
\hline & Weight $\left(\%\right.$ day $\left.^{-1}\right)$ & Length $\left(\%\right.$ day $\left.^{-1}\right)$ & Weight $\left(\%\right.$ day $\left.^{-1}\right)$ & Length $\left(\%\right.$ day $\left.^{-1}\right)$ & Weight $\left(\%\right.$ day $\left.^{-1}\right)$ & Length $\left(\%\right.$ day $\left.^{-1}\right)$ \\
\hline Control & $0.67 \pm 0.14$ & $0.26 \pm 0.03$ & $1.23 \pm 0.08$ & $0.31 \pm 0.03$ & $1.14 \pm 0.08$ & $0.38 \pm 0.03$ \\
\hline $100 \mu \mathrm{g} 1^{-1} \mathrm{HEX}$ & $0.62 \pm 0.12$ & $0.19 \pm 0.03$ & $1.09 \pm 0.10$ & $0.32 \pm 0.03$ & $1.19 \pm 0.09$ & $0.38 \pm 0.03$ \\
\hline $10 \mu \mathrm{gl}^{-1} \mathrm{ATZ}$ & $0.46 \pm 0.14$ & $0.23 \pm 0.16$ & $1.06 \pm 0.12$ & $0.31 \pm 0.03$ & $1.01 \pm 0.13$ & $0.37 \pm 0.03$ \\
\hline $100 \mu \mathrm{g} 1^{-1} \mathrm{ATZ}$ & $0.27 \pm 0.16^{\#}$ & $0.17 \pm 0.09$ & $1.72 \pm 0.13^{*}$ & $0.44 \pm 0.03^{*}$ & $1.43 \pm 0.05^{*}$ & $0.47 \pm 0.04 *$ \\
\hline
\end{tabular}

Data represent mean values \pm S.E. of $n=12\left(100 \mu \mathrm{g} 1^{-1}\right.$ ATZ $\left.n=9\right)$ fish per treatment. Significant differences from controls are indicated by an asterisk $(P<0.05$, one-way ANOVA, Dunnett's test).

${ }^{\#} P=0.06$. 

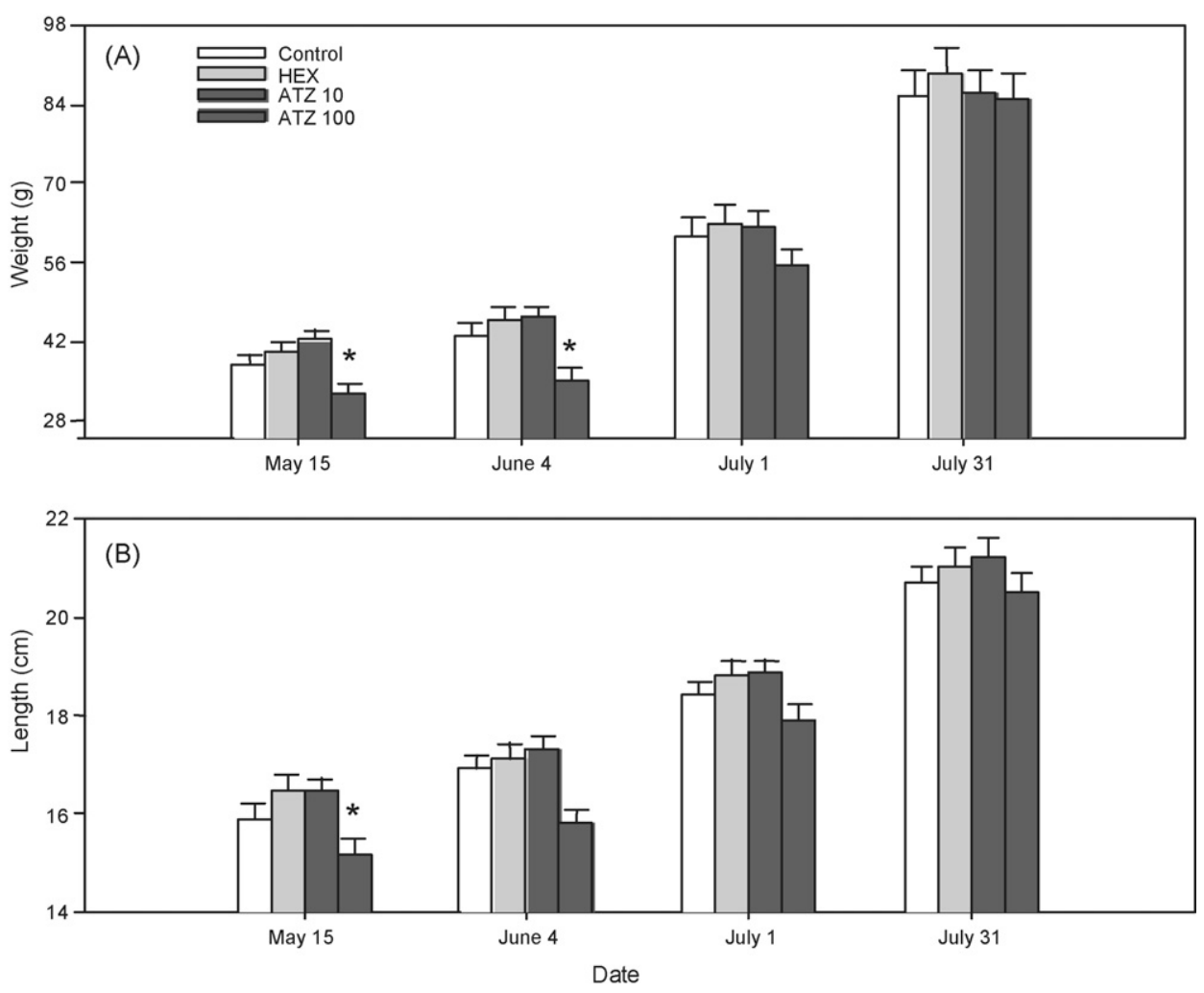

Fig. 3. Weight (A) and length (B) for smolt growth in seawater for three month that has been previously treated for 21 days with 10 and $100 \mu g 1^{-1}$ ATZ, and $100 \mu \mathrm{g} 1^{-1}$ HEX. Significant differences from controls are indicated by an asterisk $\left(P<0.05\right.$, Dunnett's test). Values are means $\pm \operatorname{standard~errors,~} n=12\left(100 \mu \mathrm{g} 1^{-1}\right.$ $\operatorname{ATZ} n=9)$ fish per treatment.

erance of Atlantic salmon smolts. This is further supported by the reduced growth in SW of smolts previously exposed to $100 \mu \mathrm{g} 1^{-1}$ ATZ. Fish treated with $100 \mu \mathrm{g} 1^{-1}$ ATZ and exposed to seawater for $24 \mathrm{~h}$ also had lower gill $\mathrm{Na}^{+}, \mathrm{K}^{+}-$ ATPase activity relative to controls. $\mathrm{Na}^{+}, \mathrm{K}^{+}$-ATPase is directly involved in salt secretion by marine fish, and its reduction may explain the observed decrease in SW tolerance. Smolts exposed to both 10 and $100 \mu \mathrm{gl}^{-1}$ ATZ had elevated plasma $\mathrm{Mg}^{2+}$ levels after SW exposure. As the kidney is primarily responsible for divalent ion regulation in fish (Marshall and Grosell, 2006) this finding suggests kidney damage following ATZ exposure.

Waring and Moore (2004) found that exposure to 10 and $22.7 \mu \mathrm{g} 1^{-1}$ ATZ (actual 8.6 and $16.6 \mu \mathrm{g} \mathrm{l}^{-1}$ ) for 7 days reduced salinity tolerance in Atlantic salmon smolts. To some degree this contrasts with the present results, in that 21-day exposure to $100 \mu \mathrm{g} 1^{-1}$ ATZ (actual $84.3 \mu \mathrm{g} 1^{-1}$ ) reduced salinity tolerance, but $10 \mu \mathrm{gl}^{-1}$ (actual $8.5 \mu \mathrm{gl}^{-1}$ ) did not. It is possible that the longer exposure used in the present study allows for compensatory mechanism(s) to develop, negating the influence of $10 \mu \mathrm{gl}^{-1}$ ATZ. Alternatively, differences in stock of fish used, prior rearing, developmental stage or other factors may account for this difference.

In the present study, the lowest dose of ATZ $\left(10 \mu \mathrm{g}^{-1}\right)$ elevated plasma $\mathrm{Na}^{+}$levels in fresh water while not affecting plasma $\mathrm{Cl}^{-}$or gill $\mathrm{Na}^{+}, \mathrm{K}^{+}$-ATPase activity. These results are identical to those of Waring and Moore (2004) at a similar dose and 7 days of treatment. Cassano et al. (2006) demonstrated that doses as low as $2 \mu \mathrm{g} 1^{-1}$ ATZ can stimulate the short-circuit current of the ventral skin of frog (Rana esculenta), resulting in stimulated $\mathrm{Na}^{+}$absorption. Increases of plasma $\mathrm{Na}^{+}$at intermediate doses of ATZ may be a compensatory response to moderate damage of ion regulatory tissue. We propose that the observed decrease in SW tolerance after exposure to $100 \mu \mathrm{g} 1^{-1}$ ATZ, may also be a compensatory response to the impacts of on the mechanisms of ion uptake. The toxic action of acid and aluminum exposure in fish is loss of ion uptake ability, and in smolts exposure to sublethal levels results in loss of salinity tolerance, presumably due to a trade-off between competing mechanisms of ion uptake and salt secretion in the gill (Saunders et al., 1983). A similar effect may occur following ATZ exposure; as smolts compensate for impacts on ion uptake they must reduce their capacity for salt secretion in SW.

In the present study, we observed a decreased feeding after 10 days exposure to $100 \mu \mathrm{g} \mathrm{l}^{-1} \mathrm{ATZ}$, and the fish were less responsive to external disturbance. Increased lethargy and decreased food consumption have been observed in Nile tilapia and catfish after exposure to 3 and $6 \mathrm{mg} \mathrm{l}^{-1}$ ATZ (Hussein et al., 1996). These authors suggest that these behavioral changes were the result of decreased acetylcholinesterase activity. However, at the lower concentrations of ATZ used in the present study, no effect of ATZ on brain cholinesterase activity was found. Furthermore, several studies conclude that ATZ alone does not affect cholinesterase activity in insects and annelids (Belden and Lydy, 2000; Anderson and Lydy, 2002; Jin-Clark et al., 2002; Lydy and Linck, 2003). 
Food deprivation can lower thyroid activity in teleost fish (Leatherland, 1982; McCormick and Saunders, 1990), but in the present study, plasma $\mathrm{T}_{4}$ and $\mathrm{T}_{3}$ levels were only affected in smolts exposed to $100 \mu \mathrm{g}^{-1}$ ATZ after $24 \mathrm{~h} \mathrm{SW}$ challenge. In salmon, thyroid hormones are involved in several aspects of smolt development including migration, morphological changes and imprinting (Hoar, 1988), but there is little evidence that thyroid hormones have a direct role in controlling salinity tolerance in salmonids (McCormick, 2001). The response of the thyroid axis to changes in environmental salinity appears to be highly variable (Leatherland, 1982), and the precise nature of the interaction between ATZ and SW exposure in affecting the thyroid axis will require further investigation.

Although not statistically significant, exposure to $100 \mu \mathrm{g} \mathrm{I}^{-1}$ ATZ resulted in a $50 \%$ increase in plasma GH levels and $20 \%$ decrease in plasma IGF-I levels. This trend is likely linked to the ATZ-induced decrease in feed intake, as food deprivation elevates plasma GH levels and suppresses plasma IGF-I levels in salmon (Björnsson, 1997; Pierce et al., 2005; Takei and Loretz, 2006). In salmonids and other teleosts, GH and IGF-I facilitate hypo-osmoregulation in $\mathrm{SW}$ by increasing of gill $\mathrm{Na}^{+}$, $\mathrm{K}^{+}$-ATPase activity and the number gill chloride cells (Sakamoto et al., 1993). The present results suggest that the impact of ATZ on salinity tolerance of smolts may not work through $\mathrm{GH}$ and IGF-I.

Prior exposure to ATZ $100 \mu \mathrm{g}^{-1}$ resulted in a decrease in growth rate during the first month in SW (Table 4). It has been suggested that reallocation of energy toward detoxification, restoring homeostasis and tissue repair following contaminant exposure has an impact on growth (Wendelaar Bonga, 1997; Levesque et al., 2002). Fish exposed to $100 \mu \mathrm{gl}^{-1}$ ATZ had reduced food intake during the exposure period, and thus may have had to replenish energy stores during the first month in SW at the expense of growth rate.

During the second and third month in SW, a significant compensatory increase in growth rate took place in the $100 \mu \mathrm{gl}^{-1}$ ATZ group (Table 4). To our knowledge this is the first demonstration of compensatory growth following exposure to contaminants, and is thus an important observation with several implications. This delayed, but substantial recovery from ATZ exposure may indicate a return to normal homeostasis and endocrine status. However, there may be costs associated with compensatory growth. An increase in feeding may expose fish to increased predation resulting in decreased survival (Morgan and Metcalfe, 2001). Recent studies indicate that compensatory growth may also result in subtle developmental deformities and reduced investment in tissue maintenance (Ali et al., 2003).

In the present study, ATZ raised hematocrit in fish after SW challenge. Hematocrit increases under stressful conditions (Pierson et al., 2004), and this can be attributed to red blood cell recruitment from the spleen (Jensen, 1987), red blood cell swelling (Wang et al., 1994) and/or hemoconcentration due to reduced plasma volume (Wilson and Taylor, 1993). Prasad et al. (1991) found that damage of the gill lamellae causes decreased respiratory capacity in Tilapia mosambica exposed to $1.1 \mathrm{mg} \mathrm{l}^{-1}$ ATZ. The increase in hematocrit we observed may therefore represent a compensatory response due to a respiratory surface reduction. Structural changes of the fish gill epithelia such as epithelial lifting, cell hypertrophy and proliferation may represent a defense response to pollutants, increasing pollutant-blood diffusion distance but reducing respiratory surface (Mallatt, 1985; Cengiz and Unlu, 2003; Oropesa-Jimenez et al., 2005).

Salmon exposed to $100 \mu \mathrm{g} \mathrm{l}^{-1}$ ATZ in FW and after SW challenge were stressed as indicated by elevated levels of plasma cortisol and glucose. Plasma glucose and cortisol levels in fish increase after exposure to many pesticides (Bhavan and Geraldine, 1997; Aguiar et al., 2004; Waring and Moore, 2004; Hori et al., 2006), including ATZ exposure $\left(100 \mu \mathrm{g}^{-1}\right)$ of carp (Gluth and Hanke, 1985). Increased cortisol may be important for mobilizing energy for responding to and repairing damage caused by contaminants, but may have negative consequences for disease resistance and growth (Wendelaar Bonga, 1997). The elevated levels of cortisol in smolts exposed to $100 \mu \mathrm{g} \mathrm{l}^{-1}$ ATZ in FW and $24 \mathrm{~h}$ in SW may be also causal for the reduced growth of these fish in the first month in SW.

A reduction in male GSI was observed after exposure to $100 \mu \mathrm{gl}^{-1}$ ATZ for 21 days. The smolts in the present study were not reproductively mature, so the significance of this observation is not clear. Decreases in GSI are known to occur in reproductive female and male fish exposed to contaminants such as mercury, cadmium, copper and pesticides (Gimeno et al., 1998; Levesque et al., 2002; Cardinali et al., 2004). Exposure of goldfish to $1000 \mathrm{\mu g} \mathrm{l}^{-1}$ ATZ decreased plasma testosterone (Spano et al., 2004). Moore and Waring (1998) found that mature male Atlantic salmon exposed to $6 \mu \mathrm{gl}^{-1}$ ATZ had decreased plasma testosterone and 11-ketotestosterone concentrations. In the present study, another possible explanation for the observed reduction in GSI is a high demand for energy and reduced food consumption of fish exposed to $100 \mu \mathrm{g}{ }^{-1}$ ATZ. Reduction in reproductive investment has been associated with the reallocation of energy in response to natural and anthropogenic stressors (Wendelaar Bonga, 1997; Maltby, 1999; Power, 2002; Ali et al., 2003).

Relative liver weight increased in females and males treated with $100 \mu \mathrm{g}^{-1}$ ATZ. Changes in liver weight have been associated with vitellogenesis in both sexes (Jalabert, 2005), and with increased detoxification of xenobiotics (Zhou et al., 1999; Sepulveda et al., 2001). The observed increase in HSI following ATZ exposure is most likely due to the enhanced activity of xenobiotic biotransformation. Exposure to ATZ did not induce hepatic vitellogenin (VTG) production in male or female goldfish (100 $\mathrm{g} \mathrm{l}^{-1}$ ATZ; Spano et al., 2004) or in male carp (30 $\mu \mathrm{M}$ ATZ; Sanderson et al., 2001). Also, estrogens and xenoestrogens that induced plasma VTG levels are positively correlated to total and protein-bound plasma $\mathrm{Ca}^{2+}$ levels (Björnsson et al., 1989; McCormick et al., 2005). In the present study, total plasma $\mathrm{Ca}^{2+}$ was reduced by ATZ, indicating that the elevated HSI is not likely due to ATZ-induced VTG.

Atlantic salmon smolts exposed to HEX did not show any effects on plasma ions, glucose, protein, cholinesterase activity or hormones involved in smolting, except for a reduction in gill $\mathrm{Na}^{+}, \mathrm{K}^{+}$-ATPase activity. The physiological relevance of this is unclear, as no effect on salinity tolerance was observed. Under the conditions imposed in this study, there was no effect of 
HEX on salinity tolerance or other osmoregulatory parameters in Atlantic salmon smolts.

\section{Conclusion}

In the present study, HEX was generally without effect, whereas ATZ at $100 \mu \mathrm{gl}^{-1}$ (actual $84 \mu \mathrm{gl}^{-1}$ ) caused perturbations of ion homeostasis in FW, and loss salinity tolerance and decreased growth in SW. Reductions in salinity tolerance are associated with reduced performance in SW and lower adult return rates (Handeland et al., 1996; McCormick et al., 1998). Levels as high as $100 \mu \mathrm{gl}^{-1}$ ATZ (actual $84 \mu \mathrm{gl}^{-1}$ ) are relatively rare in nature, especially in flowing water. It should be noted, however, that the present study were carried out for only 21 days and under relatively benign conditions. In the wild, fish are likely to be exposed prolonged periods as ATZ is relative persistent in FW with a half-life up to 350 days depending on the environmental conditions (Tavera-Mendoza et al., 2002). The presence of other stressors such as changes in temperature, food availability, water flow, $\mathrm{pH}$ or other contaminants may lower the threshold for impacts of ATZ. The present research indicates that ATZ at sublethal levels under laboratory conditions has the capacity to alter normal physiological function of Atlantic salmon smolts that may compromise their competitive ability and predator avoidance leading to a higher mortality in nature.

\section{Acknowledgements}

We thank the White River National Fish Hatchery, US Fish and Wildlife Service for providing the fish used in these studies. Special gratitude to S. Petsch (UMass-Amherst) for the use of the GC-MS and V. Gomez for the water analysis. We thank D. Baker, A. Keyes, D. Lerner, M.Y. Monette, M. O’Dea and A. Regish for their help in carrying out this study, and B. Egnér for the GH and IGF-I analysis. Dupont Co. helpfully provided the Velpar. K.N.P. received fellowship support from the Atlantic Salmon Federation, Richard Cronin Fisheries Research Fund, Equal Opportunities Section-American Fisheries Society, National Hispanic Scholarship Fund and Northeast Alliance for Graduate Education and the Professoriate (NSF). The study was further supported by the Swedish Research Council for Environment, Agricultural Sciences and Spatial Planning (FORMAS).

\section{References}

Aguiar, L.H., Morales, G., Avilez, I.M., Altran, A.E., Correa, C.F., 2004 Metabolical effects of Folidol 600 on the neotropical freshwater fish matrinxa, Brycon cephalus. Environ. Res. 95, 224-230.

Ali, M., Nicieza, A., Wootton, R.J., 2003. Compensatory growth in fishes: a response to growth depression. Fish Fish. 4, 147-190.

Alvarez, M., Fuiman, L.A., 2005. Environmental levels of atrazine and its degradation products impair survival skills and growth of red drum larvae. Aquat. Toxicol. 74, 229-241.

Anderson, T.D., Lydy, M.J., 2002. Increased toxicity to invertebrates associated with a mixture of atrazine and organophosphate insecticides. Environ. Toxicol. Chem. 21, 1507-1514.
Baatrup, E., Junge, M., 2001. Antiandrogenic pesticides disrupt sexual characteristics in the adult male guppy Poecilia reticulata. Environ. Health Perspect. 109, 1063-1070.

Belden, J.B., Lydy, M.J., 2000. Impact of atrazine on organophosphates insecticides toxicity. Environ. Toxicol. Chem. 19 (9), 2266-2274.

Bhavan, P.S., Geraldine, P., 1997. Alterations in concentrations of protein, carbohydrate, glycogen, free sugar, and lipids in the prawn Macrobrachium malcolmsonii on exposure to sublethal concentrations of endosulfan. Pestic. Biochem. Physiol. 58, 89-101.

Bolton, J.P., Takahashi, A., Kawauchi, H., Kuboto, J., Hirano, T., 1986. Development and validation of a salmon growth hormone radio-immunoassay. Gen. Comp. Endocrinol. 62, 230-238.

Björnsson, B.Th., 1997. The biology of salmon growth hormone: from daylight to dominance. Fish Physiol. Biochem. 17, 9-24.

Björnsson, B.Th., Haux, C., Bern, H.A., Deftos, L.J., 1989. 17-Estradiol increases plasma calcitonin levels in salmonid Wsh. Endocrinology 125, $1754-1760$.

Björnsson, B.Th., Taranger, G.L., Hansen, T., Stefansson, S.O., Haux, C., 1994. The interrelation between photoperiod, growth hormone, and sexual maturation of adult Atlantic salmon (Salmo salar). Gen. Comp. Endocrinol. 93, $70-81$.

Brett, J.R., Groves, T.D.D., 1979. Physiological energetics. In: Hoar, W.S., Randall, D.J., Brett, J.R. (Eds.), Fish Physiology, vol. VIII, Bioenergetics and Growth. Academic Press, New York, pp. 279-352.

Cardinali, M., Maradonna, F., Olivotto, I., Bortoluzzi, G., Mosconi, G., Polzonetti-Magni, A.M., Carnevali, O., 2004. Temporary impairment of reproduction in freshwater teleost exposed to nonylphenol. Reprod. Toxicol. $18,597-604$

Carey, J.B., McCormick, S.D., 1998. Atlantic salmon smolts are more responsive to an acute handling and confinement stress than parr. Aquaculture 168, 237-253.

Cassano, G., Bellantuono, V., Ardizzone, C., Lippe, C., 2006. Atrazine increases the sodium absorption in frog (Rana esculenta) skin. Environ. Toxicol. Chem. 25, 509-513.

Cengiz, E.I., Unlu, E., 2003. Histopathology of gills in mosquitofish, Gambusia affinis after long-term exposure to sublethal concentrations of malathion. J. Environ. Sci. Health B 38, 581-589.

Ceron, J.J., Ferrando, M.D., Sancho, E., Gutierrez-Panizo, C., Andreu-Moliner, E., 1996. Effects of diazinon exposure on cholinesterase activity in different tissues of European Eel (Anguilla anguilla). Ecotoxicol. Environ. Saf. 35, 222-225.

Davies, P.E., Cook, L.S.J., Goenarso, D., 1994. Sublethal responses to pesticides of several species of Australian freshwater fish and crustaceans and rainbow trout. Environ. Toxicol. Chem. 13, 1341-1354.

Dickhoff, W.W., Folmar, L.C., Gorbman, A., 1978. Changes in plasma thyroxine during smoltification of coho salmon, Oncorhynchus kisutch. Gen. Comp. Endocrinol. 36, 229-232.

Ellman, G.L., Courtney, K.D., Andres Jr., V., Featherstone, R.M., 1961. A new and rapid colorimetric determination of acetylcholinesterase activity. Biochem. Pharmacol. 7, 88-95.

Fisher-Scherl, T., Veeser, A., Hoffmann, R.W., Kuhnhauser, C., Negele, R.D., Ewringmann, T., 1991. Morphological effect of acute and chronic atrazine exposure in rainbow trout (Oncorhynchus mykiss). Arch. Environ. Contam. Toxicol. 20, 454-461.

Gimeno, S., Komen, H., Jobling, S., Sumpter, J., Bowmer, T., 1998. Demasculinisation of sexually mature male common carp, Cyprinus carpio, exposed to 4-tert-pentylphenol during spermatogenesis. Aquat. Toxicol. 43, 93-109.

Gluth, G., Hanke, W., 1985. A comparison of physiological changes in carp, Cyprinus carpio, induced by several pollutants at sublethal concentrations. I. The dependency on exposure time. Ecotoxicol. Environ. Saf. 9, 179-188.

Handeland, S.O., Järvi, T., Ferno, A., Stefansson, S.O., 1996. Osmotic stress, antipredator behavior, and mortality of Atlantic salmon (Salmo salar) smolts. Can. J. Fish. Aquat. Sci. 53, 2673-2680.

Hoar, W.S., 1988. The physiology of smolting salmonids. In: Hoar, W.S., Randall, D. (Eds.), Fish Physiology, vol. XIB. Academic Press, New York, pp. 275-343.

Hori, T.S.F., Avilez, I.M., Kioshi Inoue, L., Moraes, G., 2006. Metabolical changes induced by chronic phenol exposure in matrinxã Brycon 
cephalus (teleostei: characidae) juveniles. Comp. Biochem. Physiol. C 143, 67-72.

Huber, W., 1993. Ecotoxicological relevance of atrazine in aquatic systems. Environ. Toxicol. Chem. 12, 1865-1881.

Hussein, S.Y., El-Nasser, M.A., Ahmed, S.M., 1996. Comparative studies on the effects of the herbicide atrazine on freshwater fish Oreochromis niloticus and Chrysichthyes auratus at Assiut, Egypt. Bull. Environ. Contam. Toxicol. 57, 503-510.

Jalabert, B., 2005. Particularities of reproduction and oogenesis in teleost fish compared to mammals. Reprod. Nutr. Dev. 45, 261-279 (Review).

Jensen, F.B., 1987. Influences of exercise-stress and adrenaline upon intra- and extracellular acid-base status, electrolyte composition and respiratory properties of blood in tench (Tinca tinca) at different seasons. J. Comp. Physiol. 157B, 51-60.

Jin-Clark, Y., Lydy, M.J., Zhu, K.Y., 2002. Effects of atrazine and cyanazine on chlorpyrifos toxicity in Chironomus tentans (Diptera: Chironomidae). Environ. Toxicol. Chem. 21, 598-603.

Leatherland, J.F., 1982. Environmental physiology of the teleostean thyroid gland: a review. Environ. Biol. Fishes 7, 83-110.

Lerner, D.T., Björnsson, B.Th., McCormick, S.D., 2007. Effects of aqueous exposure to polychlorinated biphenyls (Aroclor 1254) on physiology and behavior of smolt development of Atlantic salmon. Aquat. Toxicol. 81, 329-336.

Levesque, H.M., Moon, T.W., Campbell, P.G.C., Hontela, A., 2002. Seasonal variation in carbohydrate and lipid metabolism of yellow perch (Perca flavescens) chronically exposed to metals in the field. Aquat. Toxicol. 60, 257-267.

Lydy, M.J., Linck, S.L., 2003. Assessing the impact of triazine herbicides on organophosphate insecticide toxicity to the earthworm Eisenia fetida. Arch. Environ. Contam. Toxicol. 45, 343-349.

Lyytikäinen, M., Kukkonen, J.V., Lydy, M.J., 2003. Analysis of pesticides in water and sediment under different storage conditions using gas chromatography. Arch. Environ. Contam. Toxicol. 44, 437-444.

Madsen, S.S., Skovbolling, S., Nielsen, C., Korsgaard, B., 2004. 17-Beta estradiol and 4-nonylphenol delay smolt development and downstream migration in Atlantic salmon Salmo salar. Aquat. Toxicol. 68, 109-120.

Maltby, L., 1999. Studying stress: the importance of organism-level responses. Ecol. Appl. 9, 431-440.

Mallatt, J., 1985. Fish gill structural changes induced by toxicants and other irritants: a statistical review. Can. J. Fish. Aquat. Sci. 42, 630648.

Marshall, W.S., Grosell, M., 2006. Ion transport, osmoregulation, and acid-base balance. In: Evans, D.H., Claiborne, J.B. (Eds.), The Physiology of Fishes. CRC Press, Boca Raton, FL, pp. 179-230.

McCormick, S.D., 1993. Methods for nonlethal gill biopsy and measurements of $\mathrm{Na}^{+}, \mathrm{K}^{+}$-ATPase activity. Can. J. Fish. Aquat. Sci. 50, 656-658.

McCormick, S.D., 2001. Endocrine control of osmoregulation in teleost. Am. Zool. 41, 781-794.

McCormick, S.D., Saunders, R.L., 1990. Influence of ration levels and salinity on circulating thyroid hormones in juvenile Atlantic salmon (Salmo salar). Gen. Comp. Endocrinol. 78, 224-230.

McCormick, S.D., Björnsson, B.Th., Sheridan, M., Eilertson, C., Carey, J.B., O’Dea, M., 1995. Increased day length stimulates plasma growth hormone and gill $\mathrm{Na}^{+}, \mathrm{K}^{+}$-ATPase in Atlantic salmon. J. Comp. Physiol. B 165, 245-254.

McCormick, S.D., Hansen, L.P., Quinn, T.P., Saunders, R.L., 1998. Movement, migration and smolting in Atlantic salmon. Can. J. Fish. Aquat. Sci. 55, 77-92.

McCormick, S.D., O’dea, M.F., Moeckel, A.M., Lerner, D.T., Bjornsson, B.T., 2005. Endocrine disruption of parr-smolt transformation and SW tolerance of Atlantic salmon by 4-nonylphenol and 17beta-estradiol. Gen. Comp. Endocrinol. 142, 280-288.

Morgan, I.J., Metcalfe, N.B., 2001. Deferred cost of compensatory growth after autumnal food shortage in juvenile salmon. Proc. R. Soc. Lond. B 268, 295-301.

Moore, A., Scott, A.P., Lower, N., Katsiadaki, I., Greenwood, L., 2003. The effect of 4-nonylphenol and atrazine on Atlantic salmon (Salmo salar L.) smolts. Aquacult. 222, 253-263.
Moore, A., Waring, C.P., 1998. Mechanistic effects of a triazine pesticide on reproductive endocrine function in mature male Atlantic Salmon (Salmo salar L.) Parr. Pest. Biochem. Physiol. 62, 41-50.

Moriyama, S., Swanson, P., Nishii, M., Takahashi, A., Kawauchi, H., DickhoV, W.W., Plisetskaya, E.M., 1994. Development of a homologous radioimmunoassay for coho salmon insulin-like growth factor-I. Gen. Comp. Endocrinol. 96, 149-161.

Neskovic, N.K., Elezovic, I., Karan, V., Poleksic, V., Budimir, M., 1993. Acute and sub-acute toxicity of atrazine to carp (Cyprinus carpio L.). Ecotoxicol. Environ. Saf. 25, 173-182.

Oropesa-Jimenez, A.L., Garcia-Cambero, J.P., Gomez-Gordo, L., RonceroCordero, V., Soler-Rodriguez, F., 2005. Gill modifications in the freshwater fish Cyprinus carpio after subchronic exposure to simazine. Bull. Environ. Contam. Toxicol. 74, 785-792.

Oulmi, Y., Negele, R.D., Braunbeck, T., 1995. Segment specificity of the cytological response in rainbow trout (Oncorhynchus mykiss) renal tubules following prolonged exposure to sublethal concentration of atrazine. Ecotoxicol. Environ. Saf. 32, 39-50.

Palma, G., Sanchez, A., Olave, Y., Encina, F., Palma, R., Barra, R., 2004. Pesticide levels in surface waters in an agricultural-forestry basin in Southern Chile. Chemosphere 57, 763-770.

Parrish, D.L., Behnke, R.J., Gephard, S.R., McCormick, S.D., Reeves, G.H., 1998. Why are't there more Atlantic salmon (Salmo salar)? Can. J. Fish. Aquat. Sci. 55, 281-287.

Pierce, A.L., Shimizu, M., Beckman, B.R., Baker, D.M., Dickhoff, W.W., 2005. Time course of the GH/IGF axis response to fasting and increased ration in chinook salmon (Oncorhynchus tshawytscha). Gen. Comp. Endocrinol. 140, 192-202.

Pierson, P.M., Lamers, A., Flik, G., Mayer-Gostan, N., 2004. The stress axis, stanniocalcin, and ion balance in rainbow trout. Gen. Comp. Endocrinol. 137, 263-271.

Power, M., 2002. Assessing fish population responses to stress. In: Adams, S.M. (Ed.), Biological Indicators of Aquatic Ecosystem Stress. American Fisheries Society, Bethesda, MD, pp. 379-429.

Prasad, T.A.V., Srinivas, T., Rafi, G.Md., Reddy, D.C., 1991. Effect in vivo of atrazine on hematology and $\mathrm{O}_{2}$ consumption in fish Tilapia mossambica. Biochem. Inter. 23, 157-161.

Sakamoto, T., McCormick, S.D., Hirano, T., 1993. Osmoregulatory actions of growth hormones and its mode of action in salmonids: a review. Fish Physiol. Biochem. 11, 155-164.

Sanderson, J.T., Letcher, R.J., Heneweer, M., Giesy, J.P., van den Berg, M., 2001. Effects of chloro-s-triazine herbicides and metabolites on aromatase activity in various human cell lines and on vitellogenin production in male carp hepatocytes. Environ. Health Perspect. 109, 10271031.

Saunders, R.L., Henderson, E.B., Harmon, P.R., Johnston, C.E., Eales, J.G., 1983. Effects of low environmental $\mathrm{pH}$ on smolting of Atlantic salmon (Salmo salar). Can. J. Fish. Aquat. Sci. 40, 1203-1211.

Sepulveda, M.S., Ruessler, D.S., Denslow, N.D., Holm, S.E., Schoeb, T.R., Gross, T.S., 2001. Assessment of reproductive effects in largemouth bass (Micropterus salmoides) exposed to bleached/unbleached kraft mill effluents. Arch. Environ. Contam. Toxicol. 41, 475-482.

Spano, L., Tyler, C.R., van Aerle, R., Devos, P., Mandiki, S.N., Silvestre, F., Thome, J.P., Kestemont, P., 2004. Effects of atrazine on sex steroid dynamics, plasma vitellogenin concentration and gonad development in adult goldfish (Carassius auratus). Aquat. Toxicol. 66, 369-379.

Stein, M.W., 1963. D-Glucose, determination with hexokinase and glucose-6phosphate dehydrogenase. In: Bergmeyer, H.U.(Ed.), Methods in Enzymatic Analysis. Academic Press, New York, p. 117.

Takei, Y., Loretz, C.A., 2006. Ion transport, osmoregulation, and acid-base balance. In: Evans, D.H., Claiborne, J.B. (Eds.), The Physiology of Fishes. CRC Press, Boca Raton, FL, pp. 179-230.

Tavera-Mendoza, L., Ruby, S., Brousseau, P., Fournier, M., Cyr, D., Marcogliese, D., 2002. Response of the amphibian tadpole xenopus laevis to atrazine during sexual differentiation of the ovary. Environ. Toxicol. Chem. 21, 1264-1267.

Wang, Y., Heigenhauser, G.J., Wood, C.M., 1994. Integrated responses to exhaustive exercise and recovery in rainbow trout white muscle: acid-base, 
phosphogen, carbohydrate, lipid, ammonia, fluid volume and electrolyte metabolism. J. Exp. Biol. 195, 227-258.

Waring, C.P., Moore, A., 2004. The effects of atrazine on Atlantic salmon (Salmo salar) smolts in fresh water and after sea water transfer. Aquat. Toxicol. 66, 93-104.

Wendelaar Bonga, S.E., 1997. The stress response in fish. Physiol. Rev. 77, $591-625$.
Wilson, R., Taylor, E.W., 1993. The physiological responses of freshwater rainbow trout, Oncorhynchus mykiss, during acutely lethal copper exposure. J. Comp. Physiol. 163, 38-47.

Zhou, T., John-Alder, H.B., Weis, J.S., Weis, P., 1999. Thyroidal status of mummichogs (Fundulus heteroclitus) from a polluted versus a reference habitat. Environ. Toxicol. Chem. 18, 2817-2823. 